NBER WORKING PAPER SERIES

\title{
INTERNATIONAL LIQUIDITY ILLUSION: ON THE RISKS OF STERILIZATION
}

\author{
Ricardo J. Caballero \\ Arvind Krishnamurthy \\ Working Paper 8141 \\ http://www.nber.org/papers/w8141
NATIONAL BUREAU OF ECONOMIC RESEARCH
1050 Massachusetts Avenue
Cambridge, MA 02138
February 2001

We thank Rudi Dornbusch, Alejandro Izquierdo, Adriano Rampini, Sergio Rebelo, Roberto Rigobon and seminar participants at MIT, Northwestern, NYU, Princeton, the Econometric Society World Congress and LACEA's Winter Camp, for their comments on this paper's precursor, International Liquidity Mamagement: Sterilization in Illiquid Financial Markets. The latter is now being refocused to its international liquidity management dimension. Caballero also thank the NSF for financial support. The views expressed herein are those of the authors and not necessarily those of the National Bureau of Economic Research.

(C) 2001 by Ricardo J. Caballero and Arvind Krishnamurthy. All rights reserved. Short sections of text, not to exceed two paragraphs, may be quoted without explicit permission provided that full credit, including $($ ) notice, is given to the source. 
International Liquidity Illusion: On the Risks of Sterilization

Ricardo J. Caballero and Arvind Krishnamurthy

NBER Working Paper No. 8141

February 2001

JEL No. E59, F31, F34, G38

\begin{abstract}
During the booms that precede crises in emerging economies, policymakers often struggle to limit capital flows and their expansionary consequences. The main policy tool for this task is a sterilization of capital inflows - essentially a swap of international reserves for public bonds. Despite its widespread use, sterilization is often criticized for its ineffectiveness and, in extreme cases, its potential backfiring. We argue that these concerns are justified when countries experience occasional external crises and domestic financial markets are illiquid. In this context, while standard Mundell-Fleming considerations may determine the impact of the sterilization on short term peso interest rates, a potentially more powerful and offsetting mechanism is triggered by the anticipated reversal of this policy in the event of an external crisis. If the instruments used in the sterilization are illiquid or result in fiscal deficits that reduce the liquidity of the private sector, then the effective dollar cost of capital, which considers the whole path of expected future rates, may be lowered rather than raised by this policy. Most importantly, this dollar cost of capital reduction does not reflect a true increase in the country's international liquidity during the external crisis and reversal, as would be the case with a successful sterilization, but just a decline in domestic private liquidity. The impact of the latter on relative asset prices creates a sort of "international liquidity illusion" which fosters rather than depress aggregate demand, and exacerbates short term capital inflows.
\end{abstract}

Ricardo J. Caballero

Massachusetts Institute of Technology

Department of Economics, E52-252A

50 Memorial Drive

Cambridge, MA 02142-1347

caball@mit.edu
Arvind Krishnamurthy

Kellogg Graduate School of Management Northwestern University

Finance Department

2001 Sheridan Road

Evanston, IL 60208

a-krishnamurthy@,nwu.edu 


\section{Introduction}

During the booms that precede crises in emerging economies, policymakers struggle to limit capital flows and their expansionary consequences. In particular, they attempt to sterilize capital inflows through an open market sale of domestic bonds or increased reserve requirements. These sterilized interventions (henceforth, sterilizations) can be extremely large. During the early 1990s in Chile, for example, the exchange intervention meant that over three quarters of its large capital inflow — amounting to around seven percent of its GDP per year - went to international reserves accumulation at the central bank. The sterilization of this intervention increased the ratio of international reserves to monetary base from 3.5 around 1990 to over 6.0 by 1993. This pattern was repeated in many emerging economies during the early 1990's, when capital flows to the developing world surged. ${ }^{1}$

Despite the fact that sterilization is the most common policy response to capital inflows, there is widespread recognition that it is not free of complications. The concerns range from its ineffectiveness to an outright backfiring, where the policy may actually fuel capital inflows, especially short term ones, and lead to an expansion rather than the desired contraction in aggregate demand.

The widespread and nearly automatic explanation for these outcomes follows the MundellFleming (MF) logic, with reference to a scenario where the authority has some exchange rate target and there is extensive capital mobility. Our starting point in this paper is to point out that this explanation is flawed, and that an alternative framework is needed to understand ineffectiveness and its extreme form, backfiring.

In the textbook Mundell-Fleming (MF) framework (Mundell 1962), the effectiveness of sterilization depends on exchange rate systems and the degree of integration to international financial markets, with the worst case for sterilization being that in which the exchange rate is fixed and the country has full access to international financial markets. In this case, the sterilization is fully undone by the private sector as capital inflows exactly offset the sterilization and the interest rate remains unchanged. Uncovered interest parity holds and the domestic interest rate is determined by the international interest rate, so that firms' cost of capital is unchanged by the central bank's action.

While the MF logic can potentially explain why policy may be ineffective, its mecha-

\footnotetext{
${ }^{1}$ Calvo et al. (1993) p. 146 write: "Sterilized intervention has been the most popular response to the present episode of capital inflows in Latin America." And so does the World Bank (1997), p. 181: "Sterilization was the most widely and intensively used policy response to the arrival of capital inflows among the countries in our sample." The sample included 22 emerging economies.
} 
nism is not consistent with the prevailing facts in emerging economies. In MF, policy is ineffective because the central bank is unable to tighten monetary conditions and hence to raise domestic peso rates. But one of the established facts is that in practice sterilization does raise domestic peso rates. Indeed the problem lies in the next - and alien to the MF framework - link; that is in the lack of connection between rises in this rate and the response of asset prices and real investment. ${ }^{2}$

Even more puzzling in the context of the traditional model is the related concern of "backfiring." Since the rise in domestic interest rates triggered by sterilization is accompanied by an increase in capital inflows, especially short term ones, policymakers warn that as it is these flows that fuel what is perceived as an excessive expansion in aggregate demand and exchange rate overvaluation, sterilization may be counterproductive (e.g. Calvo et al. 1993, Williamson 1995, Corbo and Hernandez 1996, Massad 1997). ${ }^{3}$ Again, this backfiring result does not follow from the standard MF logic, where at worst the policy is ineffective if it cannot affect monetary aggregates.

In this paper we argue that the standard analysis omits two aspects of emerging markets which are central to understanding these unusual outcomes. First, in economies where external crises are a recurrent possibility, dollars are the scarce input into production and as such the question to ask is whether policy affects the expected dollar cost of capital for firms. Thus, we argue that a full analysis of sterilization must look at the effective dollar cost of capital, not just at the current peso interest rate. Second, in economies where financial markets are underdeveloped, the outcomes of policies that rely heavily on these markets can be quite different from their developed economy counterparts. We show that if the instruments used in the intervention are illiquid, the domestic dollar cost of capital, which considers the whole path of expected future rates, may be lowered rather than raised by the sterilization. Most importantly, this dollar cost of capital reduction does not reflect a true increase in the country's international liquidity during the external crisis and reversal, as would be the case with a successful sterilization, but just a decline in domestic private

\footnotetext{
${ }^{2}$ For summaries of the evidence see, e.g., Agenor (2000) p.223 and Montiel (1996) p.212.

${ }^{3}$ In his statement on behalf of the Latin American Governors of the Fund at the joint World Bank - IMF annual meeting of the Board of Governors held in Hong Kong (1997), Massad writes: "The high rate of return on capital in a booming economy attracts large inflows of external resources... Capital flows stimulate domestic demand and could push up domestic interest rates if the monetary authority safeguards domestic equilibrium. This, in turn, could provide a further incentive for capital inflows. The probable outcome will be continued appreciation of the local currency, the resulting risk of widening the current account deficit, and the greater danger that these capital flows will be reversed, should some negative external shock occur." (page 4, our emphasis).
} 
liquidity. The impact of the latter on relative asset prices creates a sort of "international liquidity illusion" which fosters rather than depresses external indebtedness and investment in non-tradeables.

There are three central ingredients behind our analysis and results: a) a significant probability of an external crisis in the near future; b) illiquid or underdeveloped domestic financial markets; and c) the sterilization removes domestic liquidity to potentially distressed firms, as is the case when the instruments used in the sterilization are not fully liquid.

The first ingredient implies that there are times when the uncovered interest parity condition does not hold, while the second one says that during these times distressed firms may be unable to fully pledge the value of their projects to potential financiers (those with some access to international markets). In this context, the expected return on domestic loans during crises - or (henceforth) the dollar cost-of-capital for domestic firmslies above the international interest rate but below the marginal product of investment. Thus cost-of-capital during crises is determined by the relative availability of domestic liquidity (or collateral) and international liquidity (or collateral). In other words, while it is the international financial constraint that determines the spread between domestic marginal product and international interest rates, it is the domestic financial constraints that determine whether borrowers or lenders earn the spread generated by the marginal dollar.

The reversal of a sterilization during a crisis may lower the effective cost-of-capital by either raising the available international liquidity of the country (i.e., by lowering the international spread) or by lowering its domestic liquidity (i.e., by transferring a larger share of the international spread to borrowers). The former is a case of a successful sterilization, while the latter is that of an unsuccessful one. It is the latter case that we analyze in detail, and it is in this context that the third ingredient above plays its role: If the bonds used in sterilization are illiquid, in exchanging these bonds for international reserves the central bank removes domestic liquidity from the private sector and may cause the intervention to backfire. A similar outcome arises when the sterilization generates a significant tax burden to potentially distressed firms.

In conclusion, since emerging economies are characterized by the illiquidity of their financial markets and their weak links with international financial markets, ineffectiveness and backfiring must be perceived as real possibilities that reflect these pervasive structural problems rather than the particulars of an exchange rate system or monetary mechanism. 
Other related literature - methodology.

Aside from the international economics references already mentioned and to be mentioned throughout the paper, our paper belongs to a growing literature that studies the macroeconomic consequences of aggregate liquidity shortages, and the endogenous determination of the latter. Our modeling approach owes to Diamond and Dybvig's (1983) canonical model of liquidity and particularly to Holmstrom and Tirole (1998)'s departure from this model in the context of firms. Our basic model-economy is a simplified version of that in Caballero and Krishnamurthy (2001), which departs from this literature primarily in that it considers two forms of liquidity, one domestic and one international. In this sense, our basic model also relates to the recent work by Diamond and Rajan (2001), where banks' solvency constraints play a role similar to our domestic collateral in determining domestic interest rates during times of aggregate liquidity shortages.

Given our focus in this paper on the interaction between aggregate liquidity considerations and the impact of macroeconomic policies relying on asset market interventions, our work relates most closely to that of Woodford (1990) and Holmstrom and Tirole (1998). While not addressing sterilization, both present models in which policy has real effects through changes in public debt. Government policies are non-Ricardian because public debt provides the private sector with liquid assets that they are unable to create for themselves. Holmstrom and Tirole (1998) show that when there are aggregate shocks, the private sector may have a shortage of liquid assets. Public bonds make up this shortfall and government policy has real effects. In our model, on the other hand, issuing public bonds does not increase private liquidity and may do just the opposite when the policy backfires. At a more abstract level, nonetheless, the policies we study are related to theirs in that government policy acts through changing the liquidity of the assets ultimately held by the private sector.

In section 2 we lay out our basic model. We show that when domestic financial markets are underdeveloped an externality arises whereby the private sector draws down its international liquidity too fast relative to the constrained efficient outcome. More importantly, we show that in equilibrium asset prices are determined by domestic and international liquidity considerations. Section 3 begins our discussion of a sterilization, and asks the question whether actual and anticipated interventions in asset markets by the central bank (e.g. by supporting the exchange rate) always result in an implicit financial subsidy. The main result of this section is a stark Ricardian benchmark, where the private sector's actions perfectly offset those of the central bank. In a well defined sense, and despite the large ex-post impact 
of central bank interventions in a liquidity-constrained environment, it is the bond market rather than the central bank that determines the ex-ante asset prices that influence firms' financial decisions. This reference is a useful starting point in the process of identifying the mechanisms that are actually responsible for the potential financial subsidies implicit in a central bank intervention.

The main result of the paper is presented in section 4 , where we show that in an environment of financial underdevelopment, intervention may backfire if domestic bond markets are illiquid or interventions generate sizable tax burdens to potentially distressed firms. Section 5 addresses another dimension of "backfiring" often stressed in the literature. We show that our mechanism also fosters a shift in the maturity structure of capital inflows toward short term debt, even — or particularly when - the sterilization bonds are long term. ${ }^{4}$ Section 6 concludes and is followed by an extensive appendix.

\section{The Basic Setup}

This section sets the stage for our discussion of the consequences of sterilized interventions in an environment with underdeveloped domestic financial markets. The model is a simplified version of that in Caballero and Krishnamurthy (2001) and has two objectives: First, it illustrates how international and domestic liquidity considerations influence the domestic cost of capital during crises. This will be the only price in our model and will play a key role in the main section of the paper, as the novel effects of sterilization will arise from its impact on this price. We will clarify that this price is different than the domestic peso interest rate. Second, it uncovers a pecuniary externality that justifies policy intervention to reduce domestic investment during capital inflow booms.

\subsection{A Liquidity-based Model of Domestic Interest Rate Determination}

The main macroeconomic event that concerns us here is an external crisis, to be understood as a shortage of external financial resources relative to the country's needs. The crisis occurs at date 1 , and as this is the result of a binding external financial constraint, it is followed by a date 2 when the country's resources are relatively plentiful but could not be credibly pledged at date 1.

We introduce one additional date where precautions - by the private sector, and the public sector (next section) - against the crisis can be taken. Date 0 is a fully flexible

\footnotetext{
${ }^{4}$ The shift in composition of capital inflows during periods of intensive sterilization has been documented by, e.g., Montiel and Reinhart (1999) and Calvo, Leiderman, and Reinhart (1993).
} 
period when agents make investment, financing, and insurance decisions. The periods are indexed by $t=0,1,2$.

There is a unit measure of domestic agents, each endowed with $w$ units of the single (tradeable) good, that arrives at date 2 . These date 2 goods have full collateral value to foreigners (e.g., prime exports), who are willing to lend against it at dates 0 and 1 at a rate $i^{*}$ per period (henceforth all rates are dollar-rates). Foreigners play no other role in our model.

Domestics also have access to a production technology. Building a plant of size $k$ at date 0 requires them to invest $c(k)$ - with $c() \geq 0,. c^{\prime}>0$ and $c^{\prime \prime}>0-$ which yields date 2 output proportional to the size of the plant (see below). Since domestics have no resources at date 0 , they must import the capital goods and borrow from foreigners, $d_{0, f}$, to finance this investment. The financing and investment decisions are taken to maximize expected plant profits at date 2. To keep matters simple, domestics have risk neutral preferences over date 2 consumption of the single good.

Neither the plants nor their expected output are valued as collateral by foreigners. When real investments are undertaken, domestics mortgage a part of their international collateral in securing foreign funds. For now, all financing is done via fully collateralized debt contracts, thus, $d_{0, f} \leq w$.

\section{Crises}

We thus define a crisis as an event in which the financing needs of the economy exceed the aggregate external resources available to it. In our simple economy the financing need stems from the ongoing maintenance of the productive structure. The plants of one-half of the firms receive a production shock at date 1 that lowers output per plant from $R$ to $r$. However, the productivity decline can be offset by reinvesting $\theta k(\theta \leq 1)$ goods, to give date 2 output of,

$$
\tilde{R}(\theta) k=(r+\theta \Delta) k \leq R k, \quad \text { where } \quad \Delta \equiv R-r .
$$

We assume that the return on reinvestment exceeds the international interest rate: $\Delta-1>$ $i^{*}$. This means that firms borrow as much as possible from foreign lenders to finance reinvestment, and the only limit on reinvestment is the external financial constraint. Since the economy can only borrow up to $w-d_{0, f}$ goods at date 1 , the condition for a crisis is that firms' reinvestment needs be greater than the economy-wide debt capacity (see the appendix for restrictions on primitives),

$$
\frac{k}{2}>w-d_{0, f} .
$$




\section{Domestic financial markets}

Both the need for and, most importantly, the impact of central bank policy, will depend crucially on the functioning of domestic financial market. Let us turn next to outlining the role of the latter in our model.

A firm that receives a shock is said to be distressed. To cope with the shock, the firm first borrows $w-d_{0, f}$ directly from foreigners. ${ }^{5}$ After this, it must turn to the domestic firms that did not receive a shock ("intact firms") for funds. Intact firms have no output at date 1 either, so they must borrow from foreigners if they are to finance the distressed firms. This they can do up to their $w-d_{0, f}$ of financial slack.

Our domestic financial system is the institution where the economy aggregates all its international collateral at times of crisis. But why would intact firms lend to distressed firms any more than foreigners? We assume that domestics value as collateral the firm's installed assets as well. But since a perfectly functioning domestic financial market is hardly a good description of an emerging economy, and this departure has central implications for our analysis, we assume that only a fraction of the output from domestic investment can be pledged to other domestics. Domestics lend to each other using fully collateralized debt contracts, but this collateral is limited to the minimum output of $r k$. In contrast, a perfectly functioning domestic market will have the full output of $R k$ as collateral. Later on, we will associate the aggregate quantity $r k$ to the development of the domestic financial market.

These two ingredients: heterogeneity in financing needs among domestics, and a difference between foreigners and domestics in their willingness to extend finance, are necessary to give a distinct role to the domestic financial market. ${ }^{6,7}$

\section{Dollar cost of capital for firms/Expected return on domestic loans}

The price we are interested in is the rate on borrowing dollars against domestic collateral. Note that this is a dollar-cost interest rate - so in practice, it reflects the sum of peso interest

\footnotetext{
${ }^{5}$ In a crisis, this will not be sufficient to fully rebuild the plant, since if it did the total financing need of the economy would be less than the international collateral of distressed firms of $\frac{w-d_{0, f}}{2}$. This term is less than the financing need assumed during a crisis.

${ }^{6}$ See Caballero and Krishnamurthy (2000b) for a model where the asymmetry in valuation comes from the fact that domestics value nontradable goods while foreigners do not. Here, on the other hand, all final goods are tradable but there is an asymmetric valuation of less than prime assets.

${ }^{7}$ Since we do not want insurance markets to undo the ex-post heterogeneity, we assume that idiosyncratic shocks are non-observable and non-contractible. Moreover, we assume that the coordination-fragile banking equilibrium is not feasible (see Caballero and Krishnamurthy 2001).
} 
rates and expected exchange rate appreciation. This price is both the dollar cost of capital for firms in need of funds, as well as the expected return on loans for domestic lenders.

Consider the rate at date 1 on a one-period domestic loan against $r k$ units of collateral. This price is determined by both, the amount of collateral of distressed firms and the amount of international liquidity of intact ones. The aggregate collateral of distressed firms is $r k / 2$. Thus they pledge $r k / 2$ of date 2 goods to intact firms in exchange for date 1 goods of $\left(w-d_{0, f}\right) / 2$. If domestic collateral is not too limited, there is a scarcity price for the international liquidity, and the price needed to clear the domestic loan market, $i_{1}^{p}$, will exceed the international interest rate, $i^{*}: 8$

$$
i_{1}^{p}=\frac{r k}{w-d_{0, f}}-1>i^{*} .
$$

This expression highlights the effect of domestic collateral and international liquidity on date 1 cost if capital. A shortage of the latter means that $i_{1}^{p}>i^{*}$; while a shortage of the former means that the cost of capital will generally be less than the marginal product of investment at date $1(\Delta)$ :

$$
i_{1}^{p}<\Delta-1
$$

Figure 1: Liquidity Based Cost of Capital Determination

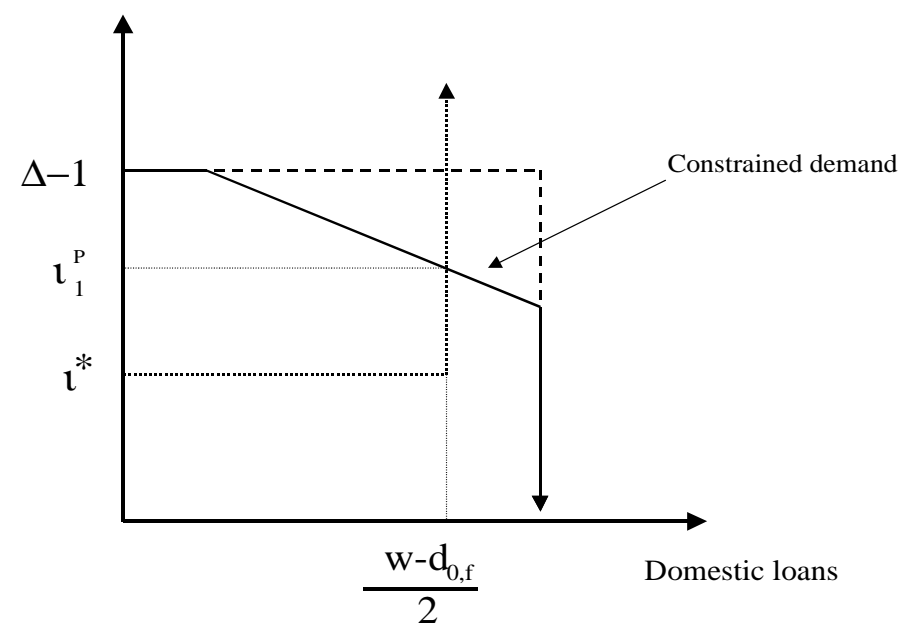

Figure 1 illustrates this. The curve in long dashes represents the marginal product of investment (less cost) for a distressed firm. That in short dashes represents the access

\footnotetext{
${ }^{8}$ By not too limited, we mean that $r k>\left(w-d_{0, f}\right)\left(1+i^{*}\right)$.
} 
to international funds from intact firms. This supply becomes vertical when the external financial constraint binds (our external crisis). The solid line represents actual demand for funds by distressed firm. It lies below the long-dashed curve because it is constrained by the limited collateral of distressed firm. It is downward sloping because a fixed amount of domestic collateral of $r k$ is able to fetch more resources as $i_{1}^{p}$ falls.

As long as the external financial constraint binds, the dollar cost of capital must lie above the international interest rate. This simply means that during times of crisis, emerging market assets must return a premium over international assets. The novel observation of our analysis is, however, that this return will generally be less than the marginal product of domestic investment. When $r k$ is low, domestic borrowers have limited collateral so that an external investment in these borrowers returns less than $\Delta$. In equilibrium, the return lies somewhere in between the international interest rate and the marginal product (the social value) of a unit of international liquidity.

In other words, in the aggregate, a shortage of international collateral yields a spread between domestic marginal product and international cost of capital. Domestic collateral, on the other hand, determines the sharing of this spread between domestic lenders and borrowers of a marginal dollar. As domestic collateral falls, a larger share of it accrues to distressed firms (borrowers). That is, in the latter example the cost of capital falls not because the economy has access to more dollars from foreigners but because it has less domestic collateral to pay for the dollars already at home.

Consider next the two period dollar cost of capital at date 0 . This is the dollar-cost rate on a loan against $r k$ of date 2 collateral made at date 0 . A domestic lender could always take one unit of international liquidity, invest it at $i^{*}$ from date 0 to date 1 , and then lend it at rate $i_{1}^{P}$ at date 1 . Indifference between this strategy and lending for two periods implies that,

$$
i_{0,2}^{P}=\sqrt{\left(1+i^{*}\right)\left(1+i_{1}^{P}\right)}-1 .
$$

The date 0 one period cost of capital is therefore just the international interest rate,

$$
i_{0}^{P}=i^{*}
$$

Since the external financial constraint does not bind at date 0, domestic assets must yield the same return as international assets - i.e. the interest parity condition holds. At date 1 , if the economy runs into a crisis and the external financial constraint binds, there is a shift in the interest parity condition. 
Interpreting the domestic cost of capital

Since the negative relation between the domestic cost of capital and the domestic financial constraints may appear as counterintuitive, it is important to pause and highlight two features of this price:

- As a matter of interpretation, $i_{1}^{p}$ is the rate for a domestic taking out a fully secured domestic loan and receiving dollar proceeds. Literally the loan is: lend the distressed firm one dollar at date 1 , and it will repay $\left(1+i_{1}^{P}\right)$ goods secured by domestic collateral at date 2 . It is the interest rate on a dollar loan made by another domestic, secured by domestic collateral, as opposed to a domestic currency interest rate (which is the interest rate emphasized in MF and other uncovered interest parity setups).

- Since it corresponds to the rate on a fully secured loan, the interest rate has no default risk built in. Rather, it is the expected return to a domestic lender of making a loan at date 1 , not the promised interest rate on a defaultable loan. This promised interest rate, which is what we typically observe, rises when a borrower has less collateral since there is a higher risk of default.

In the particular context of our model, the natural risky-rate is constant and equal to $\Delta-1$. A decline in $i_{1}^{p}$ due to a reduction in domestic collateral does not affect this rate, but it raises the risk-compensation (or, loosely, the default risk) component of it, and thus it reduces the payment for the scarce international liquidity (the liquiditypremium falls). As we show in the next section, it is the liquidity premium that matters for precautionary decisions.

Besides the visual aid in the figure above, the international interest rate - as long as it is sufficiently low to justify borrowing - plays no significant role in what follows. We shall henceforth set it to zero: $i^{*}=0$.

\subsection{Overborrowing and Incentives to Precaution}

We turn now to show how the domestic cost of capital at times of crises affect the private sector investment and precautionary decisions. This is important for two reasons. First, it will tie the justification for restrictive policies to the underdevelopment of domestic financial markets. Second, and most importantly, it will identify the channels through which a sterilization may affect, perversely or not, these decisions.

Our main results do not depend on the presence of aggregate shocks, and indeed the starkest case is made precisely when the crisis is fully predictable but still the economy runs 
into trouble. We assume that date 1 aggregate conditions are fully anticipated to be those of an external crisis - that is, the external financial constraint is binding in the aggregate. See the appendix for parameter conditions to arrive at this scenario.

Let us consider firms' incentives to precaution against the date 1 crisis and, particularly, how these incentives are affected by the domestic cost of capital. The net return on investing an extra unit of $k$ for an intact firm is composed of two pieces. On the gross return side, the firm obtains $R k$ goods at date 2 . On the cost side, it sacrifices $c^{\prime}(k)$ units of international collateral which would have yielded a return of $i_{1}^{p}$ in the domestic financial market at date 1. Thus, at the margin increasing $k$ yields an ex-post return, net of opportunity cost, of

$$
R-c^{\prime}(k)\left(1+i_{1}^{p}\right)
$$

It follows immediately from (2) that the opportunity cost of sacrificing a unit of international collateral is undervalued by an intact firm as long as $i_{1}^{p}<(\Delta-1)$. Since the demand for a unit of international collateral is constrained by the distressed firms' limited domestic collateral, the value of holding on to a unit of international collateral in order to supply it to distressed firms at date 1 is depressed relative to the socially efficient - and the distressed firm's - valuation of $\Delta$.

Now consider the same net return for a distressed firm. On the gross return side, at the margin the firm obtains $r$ unit of goods directly. But because these goods can be pledged as collateral in the domestic loan market at date 1 , the value of these $r$ goods must be multiplied by the private return that each generates (its value as a collateral asset). A loan secured by $r$ goods at date 2 , generates proceeds of $\frac{r}{1+i_{1}^{p}}$ goods at date 1 , which each can be reinvested at a gross return of $\Delta$. Thus the gross benefit to increasing $k$ is $r \frac{\Delta}{1+i_{1}^{p}}$. On the cost side, it sacrifices $c^{\prime}(k)$ units of international collateral which yield a private return of $\Delta$ to a distressed firm. Thus, at the margin increasing investment in $k$ yields a net return of:

$$
r\left(\frac{\Delta}{1+i_{1}^{p}}\right)-c^{\prime}(k) \Delta .
$$

It follows immediately from (3) that while the cost of sacrificing a unit of international collateral is properly valued by a distressed firm, the domestic investment is not. As long as $i_{1}^{p}<(\Delta-1)$, a distressed firm is able to keep some of the surplus from reinvestment by selling its overvalued domestic collateral. A central planner, on the other hand, realizes that during an external crisis only international collateral generates social surplus, and hence discounts domestic assets at $\Delta$ rather than $\left(1+i_{1}^{p}\right){ }^{9}$

\footnotetext{
${ }^{9}$ Since the analysis above takes date 0 decisions as given, the expected return on domestic loans splits
} 
Although for different reasons, both intact and distressed firms overvalue (from a social point of view) domestic investment relative to its opportunity cost - namely its opportunity cost in terms of the international collateral used. Since the ex-ante decision is based on the average of these two outcomes, it follows that firms will overinvest, overborrow and under-precaution for the date 1 shock. $^{10}$

The over-borrowing problem only arises when domestic financial markets are underdeveloped. The problem is really one of distorted asset prices due to financial constraints - limited $r k$ constrains demand so that $\Delta-1>i_{1}^{P}$. Asset market interventions such as sterilization are policies designed to alter asset prices and thereby affect real decisions. In the next sections, we shall study the effect of sterilization policy within our model in terms of possible effects on asset prices and their feedback into the underlying financial constraints and real decisions.

\section{A Ricardian Benchmark despite Liquidity Pricing}

In our model, the only relevant prices are $i_{0}^{P}$ and $i_{1}^{P}$, thus policy can only have real effects through changes in these dollar costs of capital. The date 0 rate is pinned down to be $i^{*}$ by the interest parity condition, thus we can further conclude that the effects of policy can only arise through effects on $i_{1}^{P} \cdot{ }^{11}$

the reinvestment surplus, $\Delta-1$, between domestic lenders and borrowers but it does not affect the real side of the economy. Total reinvestment is fully determined by the total availability of international collateral (that is, the sum of the international collateral available to distressed and intact firms):

$$
\frac{1}{2} \theta k=\frac{1}{2}\left(w-d_{0, f}\right)+\frac{1}{2}\left(w-d_{0, f}\right)
$$

to imply (in a crisis):

$$
\theta=2 \frac{w-d_{0, f}}{k}<1
$$

This dichotomy between the real and financial side disappears at date 0 , when domestics make their investment and portfolio decisions. When a domestic decides to make a real investment, it also makes a financial one. In particular, it gives up some of its international collateral, $w$, in exchange for domestic collateral, $r k$. It is this financial decision that is affected by $i_{1}^{p}$.

${ }^{10}$ This opens the door to international liquidity management policies, as we study in Caballero and Krishnamurthy (2000a). See also Harberger (1985) and Aizenman (1989), for alternative models of over-borrowing based on the undervaluation of the country's "monopsony" power in international financial market.

${ }^{11}$ We should note at the outset that whether a policymaker has our structure in mind when he decides to sterilize capital inflows is not what concerns us here. He may well take as reference the standard MundellFleming framework. Instead, we simply ask the positive question of how does domestic underdevelopment, as characterized in the previous section, affect the outcome of this intervention. Given this objective, our results are clearest once the standard distinction between money and bonds is removed and analysis is refocused 
The MF framework emphasizes a different price; namely, the price on borrowing pesos in the domestic market or the peso interest rate. This price plays no direct role in our model since at the margin firms always need to borrow dollars. It is possible to add a monetary side to this model to determine this peso interest rate. In its simplest neutral-money expanded form, the dollar costs of borrowing we have focused on, $i_{0}^{P}$ and $i_{1}^{P}$, would be related to these peso interest rates by a standard uncovered interest parity condition: $i_{1}^{P}=i^{\text {peso }}+e_{1} / e_{2}$, where the latter term represents the expected appreciation of the peso. Money quantities would pin down the split between the latter and peso interest rate components, neither of which would independently have any real effects in our setup. This is, of course, quite stylized, but it serves to highlight the very different mechanism at play in our model versus that in the MF framework.

Let us begin with the question of whether actual and anticipated interventions in asset markets by the central bank always have effects on private sector actions. Indeed this is a good starting place because this seems to be the prevalent view in policy circles, where committing reserves to support an exchange rate, for example, is automatically seen as an implicit subsidy to external borrowing. ${ }^{12}$ Since in our model $i_{1}^{P}$ is determined by liquidity considerations at the time of crises, it may appear that an anticipation of a central bank intervention must always have effects on the perceived cost of capital.

This implication is not as straightforward as one may think at first, however, because arbitrage actions by the private sector are a powerful force that need to be accounted for. The main result of this section is a stark Ricardian benchmark, where the private sector's actions perfectly offset those of the central bank. This reference is a useful starting point in the process of identifying the mechanisms that are actually responsible for the effects of a central bank intervention.

\subsection{The intervention}

Let us postpone issues of generality to the next sections and appendix and concentrate instead on a small central bank intervention in domestic asset markets. Concretely, by sterilization we mean a date 0 sale of $d B$ public bonds to the private sector in exchange for on the effects arising from the swap of public bonds for international reserves implicit in a sterilization of capital inflows. Alternatively, we could have given money a specific role but assumed a fixed exchange rate system. In this case, money supply actions are fully offset by capital flows, eliminating the monetary (but not ours) transmission channel as well.

${ }^{12}$ In our model $i_{1}^{p}$ can be reinterpreted as the depreciation in the real exchange rate during the crisis, relative to the date 2 exchange rate (which is one, since all goods are alike). 
$\frac{d B}{1+i_{0}^{G}}$ international liquidity (reserves), where $i_{0}^{G}$ is the interest rate on these bonds.

This intervention comes with an anticipation of how it is to be reversed during the crisis. We shall postpone a thorough discussion of this issue and for now just assume, as with the private sector, that the central bank cannot discriminate across firms but only across financial instruments. Interventions and reversals occur in open markets.

\subsection{The bond market and arbitrage}

Recall that in our setup firms have $r k$ of date 2 domestic collateral that they use as security to obtain financing. For the sake of exposition, let us refer to the claims issued against this collateral as corporate bonds - in fact, in emerging markets, financing is more likely to take the form of bank loans, but the precise instrument does not alter our message. Firms can issue up to $r k$ domestic corporate bonds.

Logically, an active bond market must place constraints on the effects of the central bank intervention. Since investors can invest in corporate and public bonds, the interest rate on these two bonds must be related. Suppose that the government issues two-period bonds at date 0 that the private sector purchases at interest rate $i_{0}^{G}$ with units of international liquidity. ${ }^{13}$ Denote the interest rate on these bonds at date 1 as $i_{1}^{G}$. At date 1 , distressed firms sell both corporate bonds and [now, one-period] government bonds to obtain funds for restructuring. The buyers in this market are intact firms and the central bank (using reserves). For an intact firm, purchasing one unit of either a corporate or government bond gives one unit of consumption at date 2. Therefore, arbitrage across these instruments will require that,

$$
i_{1}^{G}=i_{1}^{P}
$$

An immediate implication of this restriction is that the form of the intervention reversal is irrelevant for outcomes. At date 1 the government can choose to purchase either corporate bonds or repurchase its government bonds in the open market, intact firms will alter their portfolios accordingly and ensure that the prices on these securities are identical. Choosing to target purchases toward a particular asset will not boost its price above that of other assets. $^{14}$ We will revisit this issue in section 4 .

The form of reversal is irrelevant because of cross-instrument arbitrage conditions. We next show that intertemporal arbitrage renders the entire sterilized intervention irrelevant

\footnotetext{
${ }^{13}$ See the conclusion for a discussion of the realism and relevance of our assumption on the maturity of public bonds.

${ }^{14}$ This should serve as a warning to some of the informal "moral hazard" stories that see any asset support as a cause of moral hazard.
} 
for the real side of the economy. The point can be made precisely by examining interest rate determination at date 1 . Since in our setup the only equilibrium price is $i_{1}^{P}$, intervention can only have a real effect by changing this cost of capital for a firm.

Denote the private sector decisions in an economy without intervention as $\left(k, d_{0, f}\right)$. For the moment let us assume that the private sector does not re-optimize as a result of the central bank actions and take $k$ as given, which implies that private international indebtness rises by the amount of the intervention. Firms will now have $d B$ of domestic government bonds, increasing their domestic collateral to $r k+d B$ (see the appendix for a sovereign risk justification for why public bonds are not accepted by foreigners). Second, they have $\frac{d B}{1+i_{0}^{G}}$ less of international liquidity, lowering this to $w-d_{0, f}-\frac{d B}{1+i_{0}^{G}}$.

At date 1 , distressed firms sell their $d B / 2$ public bonds. In addition they sell corporate bonds against their domestic collateral totalling $\frac{r k}{2}$. The buyers of both the corporate and public bonds are intact firms and the central bank. Intact firms have $\left(w-d_{0, f}-\frac{d B}{1+i_{0}^{G}}\right) / 2$ of international liquidity, while the central bank has $d B /\left(1+i_{0}^{G}\right)$ of reserves. Thus, the post-sterilization (hence, the hat) interest rate is,

$$
\hat{i}_{1}^{P}=\frac{r k+d B}{w-d_{0, f}+\frac{d B}{1+i_{0}^{G}}}-1 .
$$

Note next that a firm at date 0 can purchase a government bond yielding $i_{0}^{G}$ for one unit of international liquidity, and then sell this bond at date 1 at an rate of $i_{1}^{G}$. Alternatively, it can invest these funds internationally at an interest rate of $i^{*}=0$ for one period. Arbitrage requires that either strategy yield the same outcome, or that rate of return on holding the government bond from date 0 to date 1 is zero. Thus intertemporal arbitrage requires that:

$$
i_{0}^{G}=i_{1}^{G}=\hat{i}_{1}^{P} .
$$

Substituting (5) into (4), we can then rewrite the post-sterilization cost of capital as:

$$
1+\hat{i}_{1}^{P}=\frac{r k}{w-d_{0, f}} \equiv 1+i_{1}^{P}
$$

That is, sterilization has no effect on the cost of capital for the firm. Since real investment depends only on $i_{0}^{P}$ and $i_{1}^{P}$, and these remain unchanged by the intervention, private decisions at date 0 are also unchanged.

\section{Sterilization Backfires}

Financial underdevelopment in emerging economies extends beyond the private sector. Particularly during crises, illiquidity also affects the secondary market for public bonds. In this 
section we show that if the central bank sterilizes by transacting in illiquid bonds, the intervention may backfire. It does so by generating an implicit financial subsidy to domestic firms. External borrowing may rise beyond the intervention, resulting in an expansion rather than the desired contraction in domestic activity. This subsidy is illusory however, in that the economy ends up with less international liquidity during crises and firms experience greater financial distress.

\subsection{The essence}

In rough terms, the intuition behind this backfiring result stems directly from the results in section 2. There we noted that a reduction in domestic collateral leads to a fall in $i_{1}^{P}$, causing firms to undervalue international liquidity, and over-borrow at date 0 . If public bonds are illiquid, then in the sterilization the central bank removes a liquid asset (international liquidity) and replaces it with an illiquid one (public bonds). The loss of liquidity causes $i_{1}^{P}$ to fall and is akin to a reduction in domestic collateral.

The point can be made precisely by focusing on a stark representation of illiquidity: suppose that there is no secondary market for government bonds so that once purchased, these bonds can only be redeemed at date 2 . On the other hand, let us continue to assume that firms can issue corporate bonds with no frictions other than the collateral constraint of $r k .^{15}$

The backfiring result appears counterintuitive, because at first glance one would think that the private sector would compensate by reducing investment and borrowing less, thereby making up for the lost liquidity. This intuition turns out to be misleading.

Fixing $i_{1}^{P}$ at its pre-sterilization level, we know that firms will not alter their investment decision at date 0 . The first step in our argument is to recognize that even though each firm has less liquid assets, the illiquidity is only apparent, since investment at dates 0 and 1 depend only on aggregate international liquidity, and this has not changed - some of it has just been reallocated to the central bank.

Taking $i_{1}^{p}$ as given, investors in our model adjust to the illiquidity by requiring a premium on the purchase of illiquid bonds rather than by cutting real investment. A firm that is intact has an opportunity cost of $i_{1}^{p}$ for each unit of international liquidity used to buy public bonds; a distressed firm, on the other hand, has an opportunity cost of $(\Delta-1)$ for

\footnotetext{
${ }^{15}$ The only feature that is essential for our results is that there is some imperfection in the secondary market of public bonds. It needs not be as extreme as we have assumed here, nor does the (short term) corporate bond market need to be more liquid than the (secondary) public bond market. See below and the appendix for these extensions.
} 
that same unit of international liquidity. Thus,

$$
i_{0}^{G}=i_{1}^{P}+\frac{\Delta-1-i_{1}^{P}}{2}>i_{1}^{P}
$$

However, the key step is to note that $i_{1}^{P}$ will not remain the same, since the loss in domestic liquidity when domestic financial markets are underdeveloped translates into a decline in $i_{1}^{P}$. To see this, fix the date 0 investment decision at $k$ (and the corresponding private external debt associated to this real investment at $d_{0, f}$ ). Distressed firms issue in total $\frac{r k-T}{2}$ corporate bonds at date 1 , where $T$ is a tax to finance the quasi-fiscal deficit caused by the government having to offer a liquidity premium on public bonds. ${ }^{16}$ This tax plays only a secondary role here (see section 4.3 for a converse case), which nonetheless reinforces our conclusion. ${ }^{17}$ The supply of international liquidity is exactly as before: $(w-$ $\left.d_{0, f}-\frac{d B}{1+i_{0}^{G}}\right) / 2$ of international liquidity from intact firms and $\frac{d B}{1+i_{0}^{G}}$ of reserves from the central bank. This gives market clearing of:

$$
\hat{\imath}_{1}^{P}=\frac{r k-T}{w-d_{0, f}+\frac{d B}{1+i_{0}^{G}}}-1 .
$$

Since $d B$ and $T$ are strictly positive, it must be the case that $\hat{\imath}_{1}^{P}<i_{1}^{P}$. It follows that in the post-sterilization equilibrium $k$ and $d_{0, f}$ must rise. That is, the policy backfires.

\subsection{Reversing the sterilization through public bonds: On the irrelevance of the reversal's instrument}

Does the fact that the reversal was done by supporting corporate bonds directly matter for our results? If so, it would appear that our result is equivalent to the moral-hazard

\footnotetext{
${ }^{16}$ We make two assumptions on taxation that continue in our spirit of introducing no extraneous distortions. First, the goverment balances its budget by raising lump-sum (non-distortionary) taxes on all citizens at date 2. Second, as we do not want to give the government the power to access future endowments that the private sector cannot promise, we assume that an increase in taxes reduces the promisable future endowments of agents (i.e. $r k$ falls by the amount of taxes). See Woodford (1990) and Holmstrom and Tirole (1999) for models where the main role of government policy is to increase the private sectors collateral by implicitly pledging it ability to tax. While this feature of governments seems realistic it clouds the issue we are trying to highlight.

${ }^{17}$ The tax-component of our story relates to one of the few existing explicit models of the perils of sterilization Calvo (1991). Building on Sargent and Wallace's (1981) unpleasant monetary arithmetics, he formally shows that, by raising domestic interest rates, the government increases its debt-service burden and creates a quasi-fiscal deficit that may jeopardize the very stabilization attempt that is supposedly being protected by the sterilization. This mechanism is different from ours in that we emphasize financial market inefficiencies rather than monetary commitment problems.
} 
caused by ex-post bailouts that has been discussed extensively in the literature. However, this is the wrong lesson to extract. As section 3 showed, the problem is not in the "bailout" per-se. Rather, our main point is that the implicit subsidy problem stems - hence this is the necessary ingredient - from the illiquidity in the instrument that the central bank transacts in.

In fact, while our explanation in terms of a reversal targeted to corporate bonds makes the implicit bailout interpretation obvious, it is actually not needed. In a few cases - e.g. Hong-Kong, Taiwan and possibly Brazil — central banks have directly supported traded private claims during crises. In others, the reversal of sterilization takes the form of a monetary expansion and an expansion of bank credit to the private sector. To the extent that the central bank backs this expansion, in fact it acquires private assets. However, the usual case of reversal is of a central bank purchasing back public rather than private assets. Next we enrich the model to address this scenario.

Let us endow firms with public bonds of $B_{0}$ that the government finances at date 2 by collecting lump sum taxes of $T_{0}$. After investment of $k$, the position of each firm comprises domestic collateral of $r k+B_{0}-T_{0}$ and international liquidity of $w-d_{0, f}$.

We move to a less extreme form of illiquidity by assuming that the sale of government bonds in secondary markets incurs a linear transaction cost. If a firm sells $B$ government bonds, then it incurs a transaction cost of $\alpha B$. With $\alpha$ between 0 and 1 , this means a seller collects proceeds on effectively $(1-\alpha) B$ bonds. $\alpha=1$ corresponds to the case of illiquidity analysed in the previous subsection. ${ }^{18}$

The central bank sterilizes by selling $d B$ bonds for $\frac{d B}{1+i_{0}^{G}}$ of international reserves. At date 1 it injects these reserves back into the market to repurchase public bonds at interest rate of $i_{1}^{G}$. Suppose that $\alpha$ is small enough compared to $\Delta$ so that it is optimal for distressed firms to sell their bonds:

$$
\frac{1+i_{1}^{G}}{1-\alpha}<\Delta
$$

Clearly, intact firms will not liquidate at date 1 since they will not wish to incur the transaction cost. Market clearing at date 1 gives the post-sterilization cost of capital,

$$
\hat{i}_{1}^{P}=i_{1}^{G}=\frac{r k+\left(B_{0}+d B\right)(1-\alpha)-T_{0}-d T}{w-d_{0, f}+\frac{d B}{1+i_{0}^{G}}}-1 .
$$

\footnotetext{
${ }^{18}$ We shall not provide a deeper model of this transaction cost but it is clear that there are many ways to motivate it. One possible interpretation is that it represents the costs and profits of a market maker.
} 
We can rewrite this expression as,

$$
\left(1+\hat{i}_{1}^{P}\right)\left(w-d_{0, f}\right)=r k+B_{0}(1-\alpha)-T_{0}+d B \frac{1+i_{1}^{G}}{1+i_{0}^{G}}\left((1-\alpha) \frac{1+i_{0}^{G}}{1+i_{1}^{G}}-1\right)-d T .
$$

Consider the term in parentheses on the right hand side. A firm that invests one dollar in a

government bond and always sells it at date 1 receives, $(1-\alpha) \frac{1+i_{0}^{G}}{1+i_{1}^{G}}$ dollars at date 1 . Since the international interest rate is zero, and the marginal investor at date 0 does not always liquidate his position at date 1 , it must be that,

$$
(1-\alpha) \frac{1+i_{0}^{G}}{1+i_{1}^{G}}<1
$$

With small liquidation costs, this is the expression that tells us that the intervention leads to a liquidity loss by firms.

Given this (i.e., that the term in parentheses on the right hand side of (8) is negative) and the fact that sterilization causes $d T>0$, we can conclude that,

$$
1+\hat{i}_{1}^{P}<\frac{r k+B_{0}(1-\alpha)-T_{0}}{w-d_{0, f}}=1+i_{1}^{P} .
$$

Thus, even if the central bank intervenes at date 1 by targeting its reserves only at public bonds, the intervention would backfire. Corporate bonds are supported indirectly by the decline in domestic liquidity.

\subsection{The relevance of distressed firms' liquidity loss}

It is important to remind the reader that domestic financial underdevelopment is a necessary ingredient for backfiring. If $r k$ were large (to highlight a large amount of domestic collateral rather than a higher productivity at date 1$), i_{1}^{P}$ would be determined by the marginal product of reinvestment $(\Delta)$ and the loss of liquidity caused by the sterilization would be inconsequential.

The other necessary ingredient for backfiring is the illiquidity of public bonds. But which aspect of this illiquidity matters? The answer is that it is the loss of liquidity to distressed firms when they purchase these bonds that matters, because it is these firms that need to liquidate their bonds before maturity. The point of this subsection is to show that the reduction in liquidity of distressed firm may arise from other channels, even when public bonds are fully liquid.

In particular, a common concern in many emerging economies stems from possible misuse of public resources. Suppose, for example, that the reserves gained in sterilization are used to bail out the failed real estate development of some highly placed officials. We show below 
that aside from the standard concerns with such practice, this action triggers a liquidity loss mechanism similar to the one we have emphasized with the illiquid public bonds. The government runs a quasi-fiscal deficit which means that distressed firms will find either that any public assets they hold will fall in value, or will find that they have an increased tax burden in the future. Either situation is akin to a domestic liquidity loss.

Let us return to the case where public bonds are fully liquid $(\alpha=0)$, but continue to assume that firms have initial holdings of government bonds of $B_{0}$. The central bank sterilizes by selling $d B$ bonds for $\frac{d B}{1+i_{0}^{G}}$ of international reserves.

Prior to the intervention, the central bank had $B_{0}$ bonds outstanding, and was expecting to raise $T_{0}=B_{0}$ of taxes at date 1 . After the intervention, the central bank has $B_{0}+d B$ bonds outstanding. If the reserves of $\frac{d B}{1+i_{0}^{G}}$ had been used to purchase bonds at date 1 , the central bank would have had resources of $d B \frac{1+i_{1}^{P}}{1+i_{0}^{G}}+T_{0}$ at date 2 . Since $i_{1}^{P}=i_{0}^{G}$ in this case, the intervention would not have affected the budget of the government,

$$
B_{0}+d B=T_{0}+d B \frac{1+i_{1}^{P}}{1+i_{0}^{G}}
$$

and the $B_{0}$ bonds would still be repaid with $T_{0}$ taxes.

Now suppose that instead of reversing the transaction in the open market, the central bank simply gives the reserves away at date 1 to a single agent (a gift). ${ }^{19}$ This agent then takes these reserves and purchases corporate (or public) bonds with them, that he redeems at date 2. The government now loses the revenue from the repurchase so that it has a deficit of:

$$
T_{0}-B_{0}-d B<0
$$

There are three options available: the government can finance the deficit by inflating and thereby reducing the value of its bonds; the government can default on a fraction of its debt causing the debt to fall in value; or the government can raise taxes to cover the shortfall. All three of these options have the same effect in our framework. To illustrate this effect, consider the default option.

Since the government has expected taxes of $T_{0}$ and issued bonds of $B_{0}+d B$, the price of each bond must be, $P_{B} \equiv \frac{T_{0}}{B_{0}+d B}$. A distressed firm at date 1 has domestic collateral of $r k-T_{0}$, and government bonds totalling $B_{0}+d B$, and international liquidity of $w-d_{0, f}$.

\footnotetext{
${ }^{19}$ Since this gift is given to an agent of infinitesimal size, the direct effect of the gift on the agents actions are infinitesimal as well. That is, traditional bailout effects are absent in this modeling.
} 
Thus market clearing at date 1 gives the post-intervention cost of capital of,

$$
\hat{i}_{1}^{P}=\frac{r k+\left(B_{0}+d B\right) P_{B}-T_{0}}{w-d_{0, f}+\frac{d B}{1+i_{0}^{G}}}-1 .
$$

As $d B$ rises, each bond falls in value, and we have a result akin to a loss of domestic liquidity. The market clearing condition can be rewritten as,

$$
\hat{i}_{1}^{P}=\frac{r k}{w-d_{0, f}+\frac{d B}{1+i_{0}^{G}}}-1<i_{1}^{P} .
$$

Again, the cost of capital for firms falls and sterilization backfires.

The government action of giving away reserves at date 1 causes the value of its bonds to fall (or future tax liabilities to rise) and results in a liquidity loss at date 0 , so that this case is mechanically the same as that of full illiquidity of government bonds.

\section{Another Symptom of Backfiring: Short-term Capital In- flows}

The observed shortening in the maturity of capital flows following sterilization is particularly interesting from our point of view (see, e.g., Montiel and Reinhart (1999) and Calvo, Leiderman, and Reinhart (1993)). The step in arriving at this result from our model is in defining short and long term debt in terms of their insurance features. One can think of long term debt as short term debt plus rescheduling insurance. Since our primitive result is one of under-insurance, a simple extension of the model presented in section 2 shows that agents undervalue the insurance component of long term debt when domestic financial markets are underdeveloped. The result is akin to our previous result on the undervaluation of international liquidity.

Consider the following model of debt maturity structure. Suppose that only a fraction $1-\psi$, where $0<\psi<1$, of $w$ is directly pledgeable to foreigners at date $1 .{ }^{20}$ Debt that is taken on against this $1-\psi$ of international liquidity is short term debt. Now suppose that the rest, $\psi w$, can be seized by foreigners at date 2 , however doing so requires payment of a monitoring cost per unit of $w$ of $\epsilon>0$ at date 2 .

A domestic firm has two choices. (A) It can take on one period debt up to the limit of $(1-\psi) w$ at the international interest rate of zero. Then at date 1 , if it needs the funds, it can roll this over and take on additional debt of $\psi w$. However, the interest rate on this

\footnotetext{
${ }^{20}$ Diamond (1991) develops a model of debt maturity structure based on liquidity risk. The sketch of our model is related but the maturity structures depends on aggregate liquidity risk.
} 
additional debt will be $\epsilon$ to compensate the foreign lenders for bearing the monitoring cost. (B) It can take on long term debt against the full $w$, in which case the foreign lenders will always pay the monitoring cost to seize the additional $\psi w$. In this case the interest rate on the long term debt is $\sqrt{1+\epsilon}-1$. Thus, domestics face an upward sloping term structure of borrowing where two period debt is more expensive than one period debt.

Let us suppose that $i_{p}^{1}<\epsilon<\frac{\Delta-1+i_{p}^{1}}{2}$. With option A, only firms that are distressed at date 1 will take on the additional debt and draw down $\psi w$, since only these firms will find it worthwhile to borrow at the high interest rate of $\epsilon$. Alternatively, with option B, all firms will have borrowed against their extra-collateral at date 0 , and the intact firms will sell the corresponding international funds at date 1 to the distressed firms. The latter option is clearly socially preferable, since the social value of an extra unit of liquidity is $\Delta-1>\epsilon$. The problem, as before, is that the return to intact firms is only $i_{1}^{p}$, which could well be below $\epsilon$ if domestic financial markets are illiquid.

In the scenario outlined above, the equilibrium is one where no firm values the insurance service of long term debt and is willing to pay the high interest rate. This comes at great cost in terms of the aggregate supply of international liquidity since a central planner would prefer that firms take on the long term debt.

Since a sterilization with illiquid bonds lowers $i_{1}^{p}$, it distorts private incentives to contract short versus long term debt even more. As a result, another symptom of backfiring is that firms shift their external borrowing towards short term debt and the capital inflowcomposition problem is worsened. ${ }^{21}$

\section{Final Remarks}

Emerging economies have poorly developed financial markets. Coupled with their large dependence on external resources, this deficiency is a source of constant instability. In this paper we have shown that the same deficiency complicates the outcome of central bank's interventions. In particular, when financial markets are underdeveloped, sterilizations may backfire and increase rather than decrease a country's external vulnerability.

Does this mean that central banks should never sterilize? Not necessarily. In deciding whether to sterilize one must weigh the importance of the liquidity mechanism we have highlighted with more traditional ingredients in its favor. First, the standard money-bonds

\footnotetext{
${ }^{21}$ Of course, in reality the maturity decision, and hence the impact of sterilization, are smoother than in our stark example. This concluding paragraph has this generalization as its background context, otherwise it must be interpreted around the point of switch.
} 
mechanism of the Mundell-Fleming model, and second, the elasticity of the international supply of funds faced by the country during the sterilization period. Having said this, the former is not a very powerful mechanism if countries have a "fear of floating," as Calvo and Reinhart (2000) have recently documented for a large group of emerging markets. As for the latter, by assuming perfect intertemporal arbitrage we have assumed that the supply of funds is locally very elastic during the sterilization period. This seems realistic for small sterilizations during times of large capital inflows. On the other hand, this also suggests that to succeed, sterilizations have to be extremely large at these times so as to break intertemporal arbitrage and hence decouple date 0 cost of capital from future rates. ${ }^{22}$.

Where should backfiring be feared the most? Our framework offers a simple answer: Economies with an intermediate level of domestic financial development, limited integration to international financial markets, and weak fiscal discipline, are the most vulnerable.

On the first characteristic, countries that have very limited financial development can never borrow and leverage enough for the international financial constraint to become a serious issue. Those that have very developed domestic financial markets, on the other hand, are sufficiently liquid so as to approximate the Ricardian benchmark that we discussed in section 3. On the second characteristic, if the country is well integrated to international financial markets then there should be no difference between international and domestic financial constraints, so that the effects we have highlighted would be absent. Finally, on the third characteristic, lack of fiscal discipline is more likely to dissipate reserves and shrink domestic liquidity through the tax burden that this implies.

In addition to these ingredients, our mechanism required that the public bonds used in sterilization be longer in maturity than the period where a crisis may take place. While this does not seem very restrictive since there are always public bonds outstanding at the time of crises, it does say that since the bonds used in sterilization are typically short term, our mechanism becomes more powerful in the proximity of crisis. Importantly, however, emerging economies are now hard at work trying to lengthen the maturity structure of public debt, including that of the bonds used in sterilization. ${ }^{23}$ While there are many good

\footnotetext{
${ }^{22}$ See this paper's precursor: Caballero and Krishnamurthy (2000a)

${ }^{23}$ See e.g. Guidotti (2000) — who is one of the architects of Argentina's liquidity management strategy and the general guidelines on this matter put together by the group of 22 shortly after the recent criseswho writes: “...public debt management and banking regulation in emerging markets should be designed to compensate the natural maturity mismatch of the private sector...it also suggests avoiding the use of short-term debt to sterilize capital inflows...." (p.30).

See also, Agenor (2000), p. 221. In his summary of the policy advise on sterilizations, he writes: "To discourage speculative short-term capital flows, medium-term sterilization bonds are generally preferable to
} 
reasons to implement this lengthening, our analysis points at a potentially serious drawback of this strategy, and suggests that this move should be accompanied by attempts to increase the liquidity of the secondary market for public bonds.

Beyond the problem of sterilization, this paper raises a series of issues that are relevant in the design of an adequate international liquidity management strategy. We are currently exploring this policy problem in more detail.

short-term securites..." 


\section{References}

[1] Agenor, P., The Economics of Adjustment and Growth, Academic Press, 2000.

[2] Aizenman, Joshua, "Country Risk, Incomplete Information and Taxes on International Borrowing," Economic Journal 99, March 1989, pp. 147-161.

[3] Allen, Franklin and Douglas Gale, "Limited Market Participation and Volatility of Asset Prices," American Economic Review 84(4), September 1994, pages 933-55.

[4] Caballero, R.J. and A. Krishnamurthy, "International and Domestic Collateral Constraints in a Model of Emerging Market Crises," forthcoming in Journal of Monetary Economics, 2001.

[5] Caballero, R.J. and A. Krishnamurthy, "International Liquidity Management: Sterilization Policy in Illiquid Financial Markets," NBER WP \# 7740, June 2000a.

[6] Caballero, R.J. and A. Krishnamurthy, "Dollarization of Liabilities: Underinsurance and Domestic Financial Underdevlopment," NBER WP \# 7792, July 2000b.

[7] Calvo, G.A., "The Perils of Sterilization," IMF Staff Papers 38-4, December 1991, pp. 921-926.

[8] Calvo, G.A., L. Leiderman, C.M. Reinhart, "Capital Inflows to Latin America: The Role of External Factors," IMF Staff Papers 40, March 1993, pp. 108-151.

[9] Calvo, G.A., and C.M. Reinhart, "Fear of Floating" mimeo University of Maryland, 2000 .

[10] Corbo, V. and L. Hernandez, "Macroeconomic Adjustment to Capital Inflows: Lessons from Recent Latin American and East Asian Experience," The World Bank Research Observer 11-1, February 1996, pp. 61-85.

[11] Diamond, D.W., "Debt Maturity Structure and Liquidity Risk," Quarterly Journal of Economics, August 1991.

[12] Diamond, D.W. and P.H. Dybvig, "Bank Runs, Deposit Insurance, and Liquidity," Journal of Political Economy 91, 1983, pp. 401-419.

[13] Diamond, D.W. and R.G. Rajan, "Liquidity Shortages and Banking Crises," U.Chicago mimeo, January 2001. 
[14] Dooley, M., "Responses to Volatile Capital Flows: Controls, Asset-Liability Management and Architecture," World Bank Conference on Capital Flows, Financial Crises and Policies, April 1999.

[15] Frankel, J.A., "Sterilization of Money Inflows: Difficult (Calvo) or Easy (Reisen)?" Estudios de Economia, 24(2), December 1997, pp. 263-285.

[16] Guidotti, P.E., "Toward a Liquidity Management Strategy for Emerging Market Economies," mimeo October 2000.

[17] Harberger, A., "Lessons for Debtor-Country Managers and Policymakers," in J.Cuddington and G.Smith (eds.), International Debt and the Developing Countries. Washington: World Bank, 1985.

[18] Holmstrom, B. and J. Tirole, "Private and Public Supply of Liquidity," Journal of Political Economy 106-1, February 1998, pp. 1-40.

[19] Massad, C.A., "Statement by Mr. Carlos Massad, Governor for Chile, Representing the Latin American Governors of the International Monetary Fund at the Annual Meetings of the World Bank and the International Monetary Fund," Hong Kong, September 23, 1997.

[20] Montiel, P. "Policy Responses to Surges in Capital Inflows: Issues and Lessons," in Private Capital Inflows to Emerging Markets, ed. by Calvo, Goldstein and Hochreiter, IEE, 1996.

[21] Montiel, P. and C. Reinhart, "Do Capital Controls and Macroeconomic Policies Influence the Volume and Composition of Capital Flows? Evidence from the 1990s," mimeo, March 1999.

[22] Mundell, R.A., "Capital Mobility and Stabilization Policy under Fixed and Flexible Exchange Rates," Canadian Journal of Economics and Political Science, 1962, pp.475485 .

[23] Sargent, T.J. and N.Wallace, "Some Unpleasant Monetary Arithmetic," Federal Reserve Bank of Minneapolis Quarterly Review, 5(3), 1981, pp. 1-17.

[24] Williamson, J., "The Management of Capital Inflows," Pensamiento Iberoamericano, January-June 1995. 
[25] World Bank, Private Capital Flows to Developing Countries: The Road to Financial Integration, Oxford University Press, 1997.

[26] Woodford, M. "Public Debt as Private Liquidity," American Economic Review, Papers and Proceedings 80 May 1990, pp. 382-88.

[27] The World Bank, East Asia: The Road to Recovery, September 1998. 


\section{A Appendix}

\section{A.1 Detailed programs, definitions and assumptions}

Let $i^{*}=0$. There are three main assumptions we have made in the model:

\section{Assumption 1 (Non-observability of Production Shock)}

The production shock at date 1 is idiosyncratic. The identity of firms receiving the shock is private information.

\section{Assumption 2 (Domestic Borrowing Constraint)}

A domestic lender can only be sure that a firm will produce rk units of goods at date 2. Any excess production based on physical reinvestment at date 1 is neither observable nor verifiable.

\section{Assumption 3 (Liquidity Bias)}

Foreigners lend to domestic firms only against the backing of $w$. Domestics lend against both $w$ and $r k$.

This gives a date 0 debt constraint with respect to foreigners of $d_{0, f} \leq w$. At date 1 , if a firm takes on additional debt with foreigners, the date 1 debt constraint is:

$$
d_{0, f}+d_{1, f} \leq w
$$

Since domestics lend against $r k$ the debt constraint for domestic lending at date 1 is,

$$
\frac{d_{1, d}}{1+i_{1}^{P}} \leq w+\frac{r k}{1+i_{1}^{P}}-d_{1, f}-d_{0, f}
$$

The program for a distressed firm at date 1 is:

$$
\begin{array}{lll}
(P 1) \quad V_{s} & \equiv \max _{\theta, d_{1, f}, d_{1, d}} & w+\tilde{R}(\theta) k-d_{0, f}-d_{1, f}-d_{1, d} \\
\text { s.t. } & (i) & d_{1, f}+d_{0, f} \leq w \\
& (i i) & \frac{d_{1, d}}{1+i_{1}^{P}}+d_{1, f}+d_{0, f} \leq w+\frac{r k}{1+i_{1}^{P}} \\
& (i i i) & \theta k=d_{1, f}+\frac{d_{1, d}}{1+i_{1}^{P}} \\
& (i v) & \theta \leq 1 .
\end{array}
$$

Constraints $(i)$ and $(i i)$ are balance sheet constraints (net marketable assets greater than liabilities), while constraint (iii) reflects that new investment must be fully paid with the resources received by the firm at date 1 in taking on debts of $d_{1, f}$ and $d_{1, d}$. Constraint $(i v)$ is purely technological.

An intact firm at date 1 has only one decision: how much finance will it extend to the distressed firm. Suppose that the firm accepts claims at date 1 of $x_{1, d}$ (face value of date 2 goods) in return for making a date 1 contribution of $\frac{x_{1, d}}{1+i_{1}^{P}}$ which is financed with new external debt $d_{1, f}^{s}$. Then,

$$
\begin{array}{rrl}
(P 2) \quad V_{i} \equiv \max _{x_{1, d}} & w+R k+x_{1, d}-d_{0, f}-d_{1, f}^{s} \\
& & d_{0, f}+d_{1, f}^{s} \leq w \\
& & \frac{x_{1, d}}{1+i_{1}^{P}} \leq d_{1, f}^{s}
\end{array}
$$


Date 0 problem. At date 0, a firm looking forward to date 1 can expect to find itself as either distressed or intact. Thus the decision at date 0 is,

$$
\begin{aligned}
(P 3) \max _{k, d_{0, f}} & \left(V_{s}+V_{i}\right) / 2 \\
\text { s.t. } & d_{0, f} \leq w \\
& c(k)=d_{0, f} .
\end{aligned}
$$

Equilibrium. Market clearing in the domestic debt market at date 1 (capital letters denote aggregate quantities) requires that the aggregate amount of domestic debt taken on by distressed firms is fully funded by intact firms:

$$
\begin{aligned}
D_{1, d} & =\frac{1}{2} d_{1, d} \\
X_{1, d} & =\frac{1}{2} x_{1, d} .
\end{aligned}
$$

Therefore, market clearing,

$$
D_{1, d}=X_{1, d}
$$

determines the cost of capital, $i_{1}^{P}$.

An equilibrium of this economy consists of date 0 and date 1 decisions, $\left(k, d_{0, f}\right)$ and $\left(\theta, d_{1, f}, d_{1, d}, x_{1, d}\right)$, respectively, and prices $i_{1}^{P}{ }^{24}$ Decisions are solutions to the firms' problems (P1), (P2), and (P3) given prices. At these prices, the market clearing condition (10) holds.

Let us now study equilibrium in more detail. Starting from date 1, consider financing and investment choices of the distressed firm given $\left(k, d_{0, f}\right)$. First, if $\Delta \geq 1$, then the distressed firm would choose to save as many of its production units as it can. It may borrow up to its international debt capacity,

$$
d_{1, f}=w-d_{0, f}
$$

If the amount raised from international investors, $w-d_{0, f}$, is less than the funds needed for restructuring, $k$, the firm will have to access the domestic debt market to make up the shortfall. It will choose to do this as long as $\Delta-1 \geq i_{1}^{P}$, or the return on restructuring exceeds the domestic cost of capital. If the firm borrows fully up to its domestic debt capacity, it will issue debt totalling,

$$
d_{1, d}=r k,
$$

and raise funds with which to pay for imported goods of $\frac{r k}{1+i_{1}^{P}}$. As long as the sum of $\frac{r k}{1+i_{1}^{P}}$ and the right hand side of (11) is more than the borrowing need, the firm is unconstrained in its reinvestment

\footnotetext{
${ }^{24}$ Where we have used the fact that at equilibrium prices, $\frac{x_{1, d}}{1+i_{1}^{P}}=d_{1, f}^{s}$.
} 
at date 1 and all production units will be saved. In this case, the firm will borrow less than its domestic debt capacity (and perhaps less than the international debt capacity).

Intact firms can tender at most their excess international debt capacity of $w-d_{0, f}$ in return for purchasing domestic debt. They will choose to do this as long as the return on domestic loans exceeds the international rate, $i_{1}^{P} \geq 0$.

Assume for a moment that $\Delta-1 \geq i_{1}^{P} \geq 1$ so that distressed firms borrow as much as they can, and intact firms lend as much as they can. Then, in total the economy can import $w-d_{0, f}$ goods, which is directed to the distressed firms. A necessary condition for all production units to be saved is that,

$$
\frac{k}{2} \leq w-d_{0, f}
$$

We shall refer to this constraint as the international liquidity constraint. When neither (12) nor (13) binds, all production units are saved. Since there is excess supply of funds from intact firms relative to domestic demand for funds, there is no international liquidity premium, and $i_{1}^{P}$ is equal to the international interest rate (zero).

The other extreme case is when both (12) and (13) bind. Equilibrium in the domestic debt market requires that,

$$
\frac{r k}{1+i_{1}^{P}}=w-d_{0, f}
$$

Since (12) binds, distressed firms borrow fully up to their debt capacity. As (13) binds, intact firms purchase this debt with all of their excess funds. Solving for $i_{1}^{P}$, yields

$$
i_{1}^{P}=\frac{r k}{w-d_{0, f}}-1>0 .
$$

That is, in this case the $i_{1}^{P}$ is above the international interest rate in order to clear the domestic market for scarce international liquidity. One half times the numerator in (14) corresponds to the transferable domestic resources owned by distressed firms.

Define the index of domestic illiquidity as the difference between the marginal profit of saving a distressed production unit and the domestic interest rate of $i_{1}^{P}$. When (13) binds, this is,

$$
s_{d}=\Delta-i_{1}^{P}-1
$$

Equilibrium at date 1 can place the economy in one of four regions, classified according to which of the two (domestic and international) liquidity constraints are binding. In the text, we focused on a scenario, where both liquidity constraints are binding. At the aggregate level, the economy is liquidity constrained with respect to foreigners; at the individual level, firms are liquidity constrained 
with respect to other domestics since they are selling all of their domestic liquidity in aggregation; real investment is constrained; domestic spreads are positive; and the domestic cost of capital of $i_{1}^{P}$ is above the international interest rate. This is the most interesting configuration for the preventionpolicy questions we address.

\section{Technical Assumption 1 (Conditions for Crisis)}

Assume that:

$$
\begin{aligned}
1 & \leq r \\
c^{\prime-1}\left(\frac{\Delta+R}{1+\Delta}\right)+c\left(c^{\prime-1}\left(\frac{\Delta+R}{1+\Delta}\right)\right) & <w<c^{-1}\left(\frac{1+R}{2 \Delta}\right)+c\left(c^{\prime-1}\left(\frac{1+R}{2 \Delta}\right)\right) .
\end{aligned}
$$

The assumption guarantees that in equilibrium $\Delta-1>i_{1}^{P}>0$ and $\theta<1$. This ensures focus on a case where both (12) and (13) bind.

Underprovision of International Liquidity. When both liquidity constraints are binding at date 1 , the decentralized equilibrium is constrained inefficient. A central planner can effect a Pareto improvement by forcing the private sector to decrease $\left(k, d_{0, f}\right)$, thereby increasing the international liquidity of the economy. The welfare gain from this intervention rises with the index of domestic illiquidity, $s_{d}$.

Proof: First let us rewrite (P3), substituting in the value function from (P1) and (P2). A date 0 choice of $\left(k, d_{0, f}\right)$ result in date 2 resources (net of any contracted debt) of,

$$
\left(w-d_{0, f}\right) \Delta+\frac{r k}{1+i_{1}^{P}} \Delta
$$

if the firm is distressed. This is because $\left(w-d_{0, f}\right)$ is direcly pledged to foreigners, and the proceeds invested at the project return of $\Delta$. The $r k$ of domestic liquidity is sold at $1+i_{1}^{P}$, and the proceeds invested at $\Delta$. If the firm is intact, date 2 resources are,

$$
\left(w-d_{0, f}\right) 1+i_{1}^{P}+R k .
$$

Thus the date 0 program is,

$$
\begin{array}{ll}
(P 4) \max _{k, d_{0, f}} \quad\left(R+r \frac{\Delta}{1+i_{1}^{P}}\right) k+\left(\Delta+1+i_{1}^{P}\right)\left(w-d_{0, f}\right) \\
\text { s.t. } \quad w \geq d_{0, f} \\
& c(k)=d_{0, f}
\end{array}
$$

Consider the program for a central planner who directly chooses $\left(k, d_{0, f}\right)$ to maximize the equally weighted sum of utilities of agents in this economy. To do this we simply substitute the expression for $1+i_{1}^{P},(14)$, into the objective of $(\mathrm{P} 4)$, arriving at an expression that is free of prices. The program for a central planner is,

$$
\begin{array}{ll}
(P 5) \max _{K, D_{0, f}} \quad & (R+r) K+2 \Delta\left(W-D_{0, f}\right) \\
& \text { s.t. } \quad w \geq d_{0, f} \\
& c(K)=D_{0, f}
\end{array}
$$


The solutions to (P5) are the constrained efficient decisions of the economy. The only difference between the programs (P4) and (P5) is in the objective. Subtracting the objective in (P5) from that of (P4) we arrive at,

$$
s_{d}\left(\frac{r}{1+i_{1}^{P}} K-\left(W-D_{0, f}\right)\right) .
$$

At a given equilibrium, this term must be zero. But it is apparent that individuals and the central planner value a marginal unit of international liquidity and domestic liquidity quite differently. Moreover, this misvaluation is directly proportional to $s_{d}$, the domestic illiquidity index.

The first order condition of (P5) gives,

$$
c^{\prime}(K)=\frac{R+r}{2 \Delta}
$$

while that of (P4) yields,

$$
c^{\prime}(k)=\frac{R+r \frac{\Delta}{1+i_{1}^{P}}}{\Delta+1+i_{1}^{P}}
$$

\section{A.2 Sovereign risk as justification for liquidity bias}

In assumption 3, we stated that foreigners only hold claims on $w$. Claims on $r k$ (corporate bonds) and claims on domestic government bonds were assumed to be part of domestic collateral only. Sovereign risk is one possible justification for this assumption.

\section{Assumption 4 (Sovereign Risk)}

The government suspends convertibility at date 1 and imposes two restrictions on exchange:

- Foreigners are prevented from transporting any date 2 goods from within the economy across the border.

- Any international liquidity holdings of the government/central bank are released to the private sector only on presentation of an invoice for imported goods.

At date 1 the government will suspend convertibility and repudiate any date 2 claims directly owed to foreigners. Foreigners holding claims directly on export sector revenues $(w)$ are unaffected by suspension, since they can seize these receivables directly. However a foreigner holding a claim on a domestic firm or a domestic government bond has only one choice. He must sell these claims to a domestic agent who has some international liquidity and exit. That is domestic claims are internationally liquid only to the extent that they can be exchanged for the private sector's international liquidity at date 1.

Liquidity Bias and Foreigner's Short Horizons. Foreigners have short horizons with respect to domestic claims. Any domestic claim acquired at date 0 will always be sold at date 1. Claims on international liquidity are free of this short horizon. 
Proof: Suppose that the private sector holds $B$ goverment bonds, $r K$ domestic claims, and has $w-d_{0, f}=0$. Suppose foreigners hold $B_{f}$ government bonds. We show that $B_{f}=0$ in equilibrium.

When $w-d_{0, f}=0$, the government controls all of the international liquidity in the economy. If the government suspends convertibility at date 1 , it only releases reserves when shown an invoice for an imported good to fulfill investment plans. The government from oale of $B+B_{f}$ bonds at date 0 has $\frac{B+B_{f}}{L_{0}}$ of reserves.

Case I: Suppose that the foreigner goes to the central bank with $B_{f}$ bonds and an invoice for $\frac{B_{f}}{1+i_{1}^{G}}$ import goods. Then the government releases $\frac{B_{f}}{1+i_{1}^{G}}$ reserves to the foreigner that it uses to pay the cost of the import good. The foreigner must sell this to the domestic distressed firm for $B_{f}$ domestic claims. However, these claims have no value to foreigners since they will surely be repudiated at date 2 . Thus, $B_{f}=0$.

This argument may be construed as unrealistic on grounds that foreigners could take the imported goods and liquidate them outside the country for international liquidity, but its fairly easy to deal with these issues. If there is any liquidation cost in this transaction, foreigners would prefer not to hold domestic claims, since they must always bear this cost, while domestics never bear the cost. An alternative objection is that firms could over-invoice for imported goods as they do routinely during periods of capital-controls. That is they claim higher prices than actual ones for their goods, thereby getting their hands on more valuable international reserves. Suppose that a firm can get away with over-invoicing by a multiple of $M>1$. A firm that tenders one unit of domestic claim receives $\frac{1}{M\left(1+i_{1}^{G}\right)}$ import goods, and $\frac{M-1}{M\left(1+i_{1}^{G}\right)}$ international reserves. The import goods can be sold to a distressed firm, for $\frac{1}{M}$ domestic claims. The international reserves can now be sold to a foreigner to redeem some of the foreigner's bonds. Foreigners selling $B_{f}$ bonds can receive at maximum $\frac{M-1}{M} \frac{B+B_{f}}{1+i_{0}^{G}}$ reserves. Thus let,

$$
i_{1, f}^{B}=\frac{B_{f}}{\frac{M-1}{M} P_{B}\left(B+B_{f}\right)}-1
$$

This is the discount that foreigners sell their bonds at. In equilibrium, foreigners will hold only enough bonds so that $i_{1, f}^{B}=i_{1}^{G}$. This means that a fraction $\frac{M-1}{M}$ of international reserves can be promised away to foreigners by the private sector at date 0 . Over-invoicing creates a leak in the system.

Case II: Suppose the foreigner goes to a domestic investor and offers $B_{f}$ bonds for international liquidity. Since $d_{0, f}=w$, domestics have none, and can only get international liquidity by tendering bonds to the central bank. Suppose a domestic tenders $B$ bonds to the central bank, shows import goods of $\frac{B}{1+i_{1}^{G}}$ and then receives $\frac{B}{1+i_{1}^{G}}$ reserves. However these reserves will exactly pay for the import goods, hence the domestic will be left with no liquidity to offer foreigners.

Finally let us show that only distressed firms will sell bonds to the central bank for its international reserves. 
Case III: Either distressed or intact firms can tender $r K+B-T$ to the government for $\frac{B+B_{f}}{1+i_{0}^{G}}$ of reserves. If intact firms tender, they onsell the imported goods to distressed firms in exchange for some of $r K+B-T$ of distressed firms. Suppose an intact firm tenders one domestic claim, it receives $\frac{1}{1+i_{1}^{G}}$ import goods, which it sells to the distressed firm for $1+i_{1}^{G}$ domestic claims. Thus it is indifferent between tendering and not. Assume that it does not.

Distressed firms receive all imported goods totalling,

$$
\frac{r K+B-T}{1+i_{1}^{G}}
$$

This is exactly equal to $\frac{B+B_{f}}{1+i_{0}^{G}}$ which is all of the government's reserves. Thus when only distressed firms tender, this is an equilibrium. 